\title{
ANALISIS STRATEGI PENGELOLAAN KUALITAS KEHIDUPAN KERJA DALAM MENINGKATKAN KINERJA KARYAWAN UD. ZIDAN COLLECTION TAYU-PATI
}

\author{
Tina Martini dan Windy Vinorika Yuli Astuti \\ Sekolah Tinggi Agama Islam Negeri Kudus \\ tinastainkds@gmail.com
}

\begin{abstract}
This study aims to analyze the strategy of quality management of UD working life. Zidan Collection in improving employee performance and what factors become supporters and obstacles in improving the performance of UD employees. Zidan Collection. This research includes field research and case study with descriptive qualitative approach. Primary data sources are sourced from direct interviews with UD convection leaders and employees. Zidan Collection, while secondary sources are obtained through documents owned by UD. Zidan Collection. Data collection techniques in this study are interviews, observation and documentation. Data analysis techniques with data reduction, data presentation and conclusion drawing. Test the credibility of the data with extension of observation, increasing perseverance, and triangulation. This research resulted that, firstly strategy of quality management of UD working life. Zidan Collection in improving the performance of employees is done through the development of quality aspects of work life, namely: open interactive communication, employee involvement in conflict resolution through deliberation, career development by providing training, employment participation by involving all employees in the meeting, build employees pride with undertake recreation once a year and provide THR, appropriate compensation by awarding bonuses to achievers, environmental safety by providing a clean, safe and comfortable working environment with workplace music, work safety by making all employees as permanent employees, as well as occupational health given in the form of including all employees as members of BPJS employment. Second, the factors that become supporters in improving the performance of UD employees. Zidan Collection is the provision of bonuses to employees, the existence of insurance for employees, and the availability of facilities that
\end{abstract}


support employee comfort in work. While the inhibiting factor is the level of employee education is still low and most employees are housewives.

Keywords: Quality of Work Life, Employee Performance

\section{A. Pendahuluan}

Strategi untuk selalu dapat berkompetisi adalah dengan cara memperkuat kapasitas organisasi dan sumber daya manusia yang dimiliki. Peranan manajemen sumber daya manusia sangat penting bagi perusahaan dalam mengelola, mengatur, dan memanfaatkan karyawan, sehingga dapat berfungsi secara produktif untuk tercapainya tujuan perusahaan (Anwar : 2013). Menurut Marihot Tua (dalam Danang, 2013) manajemen sumber daya manusia merupakan aktivitas yang dilakukan untuk merangsang, mengembangkan, memotivasi, dan memelihara kinerja yang tinggi dalam organisasi. Manajemen sumber daya manusia juga dapat didefinisikan sebagai serangkaian kegiatan pengelolaan dan pengorganisasian dari fungsi sumber daya manusia dalam rangka untuk mencapai tujuan organisasi secara efektif dan efisien (Wahibur: 2011)

Sumber daya manusia memiliki peran strategis dalam memberikan nilai tambah bagi organisasi untuk mencapai keunggulan kompetitif. Perubahan lingkungan dan teknologi yang begitu cepat sekarang ini, menjadikan sumber daya manusia sebagai faktor yang menentukan kemampuan perusahaan dalam memenangkan persaingan. Paradigma lama yang membanggakan teknologi dan mesin-mesin akan bergeser menuju paradigma baru dimana human capital memegang peranan penting. Pandangan perusahaan terhadap sumber daya manusia juga mengalami perubahan, yang dulu menganggap karyawan sebagai bagian dari faktor produksi yang harus mengikuti aturan-aturan dan berfungsi untuk memenuhi target produksi, bergeser pada pandangan bahwa sumber daya manusia sebagai asset yang sangat berharga, karena sebagai penentu kelangsungan hidup perusahaan dimasa yang akan datang.

Sebagai asset terpenting, keberdaan sumber daya manusia harus dipelihara supaya tetap dalam organisasi. Pemeliharaan merupakan suatu langkah perusahaan dalam mempertahankan karyawan agar tetap mau bekerja dengan baik dan produktif, 
dengan cara memperhatikan kondisi fisik, mental dan sikap karyawan agar tujuan perusahaan dapat dicapai. Fungsi pemeliharaan memiliki peran penting dan harus menjadi perhatian manajemen sumber daya manusia, karena kurang diperhatikan manajemen akan berpengaruh terhadap penurunan semangat kerja, kepuasan kerja, komitmen, serta meningkatkan absensi dan keinginan untuk pindah. Dengan perhatian manajemen terhadap karyawan akan meningkatkan semangat kerja, berdisiplin tinggi, dan komitmen karyawan dalam mendukung pencapaian tujuan perusahaan. Dalam pemeliharaan karyawan, kualitas kehidupan kerja dapat digunakan sebagai usaha untuk menjaga kesehatan fisik dan mental karyawan dari berbagai tekanan pekerjaan, sehingga karyawan betah di perusahaan. Adanya kualitas kehidupan kerja juga dimaksudkan agar dilakukan perbaikan terus menerus untuk membangkitkan kinerja karyawan.

Kualitas kehidupan kerja merupakan terjemahan dari quality of work life (QWL). Stan Kossen (dalam Cepi, 2015) mengemukakan bahwa kualitas kehidupan kerja mengacu kepada bagaimana efektifnya lingkungan pekerjaan memenuhi keperluan-keperluan pribadi dan nilai-nilai karyawan. Sedangkan kualitas kehidupan kerja merupakan program yang mencakup cara untuk menciptakan rasa aman dan kepuasan dalam bekerja, agar sumber daya manusia di lingkungan perusahaan menjadi kompetitif (Hadari: 2011). Keberadaan kualitas kehidupan kerja dalam keseharian kerja dinilai memiliki keterkaitan yang perlu diperhatikan oleh para pimpinan organisasi karena terkait dengan produktivitas dan kinerja pegawai. Kualitas kehidupan kerja mengemukakan pentingnya penghargaan terhadap manusia dalam lingkungan kerjanya yang ditinjau dari segi komunikasi yang terbuka, keterlibatan karyawan dalam penyelesaian konflik dan partisipasi kerja, pengembangan karier, kompensasi yang layak, keselamatan lingkungan, keselamatan kerja, serta pengembangan perasaan bangga karyawan. Kualitas kehidupan kerja merupakan salah satu bentuk filsafat yang diterapkan manajemen dalam mengelola organisasi pada umumnya dan sumber daya manusia pada khususnya.

Kualitas kehidupan kerja merupakan masalah utama yang patut mendapat perhatian organisasi, karena hal tersebut merujuk 
pada pemikiran bahwa kualitas kehidupan kerja dipandang mampu untuk meningkatkan peran serta dan sumbangan para anggota atau karyawan terhadap organisasi. Menurut May dan Lau, kualitas kehidupan kerja mempunyai pengaruh positif dan signifikan terhadap kinerja perusahaan. Adanya kualitas kehidupan kerja juga menumbuhkan keinginan para karyawan untuk tetap tinggal dalam organisasi. Hal ini juga selaras dengan pendapat Elmuti dan Kathawala yang menyatakan bahwa adanya hubungan positif antara praktek kualitas kehidupan kerja dengan kinerja karyawan (Arifin: 2012). Dengan demikian dapat disimpulkan, jika kualitas kehidupan kerja suatu organisasi baik, maka kinerja karyawan akan menjadi lebih baik. Kinerja yang bagus akan dihasilkan pekerja jika mereka dihargai dan diperlakukan seperti layaknya manusia dewasa. Pada dasarnya kinerja karyawan merupakan hasil proses yang kompleks, baik berasal dari diri pribadi karyawan maupun upaya strategis perusahaan.

UD. Zidan Collection merupakan perusahaan yang bergerak dalam bidang konveksi yaitu memproduksi pakaian jadi yang berada di wilayah kecamatan Tayu, kabupaten Pati. Perusahaan ini sudah berdiri sejak tahun 2006 dan sekarang memiliki 50 karyawan. Walaupun lokasi pabrik UD. Zidan Collection berada di daerah pedesaan, tetapi UD. Zidan Collection telah berusaha mengelola kualitas kehidupan kerjanya dengan sebaik mungkin agar karyawan merasa nyaman, termotivasi dan kinerjanya meningkat. Pimpinan perusahaan selalu membaur atau berkomunikasi secara terbuka dengan bawahan dan memberikan karyawan kesempatan dalam memecahkan konflik di perusahaan maupun konflik antar karyawan secara terbuka, jujur dan adil. Karyawan juga diikutsertakan dalam proses pengambilan keputusan dan pelaksanaan pekerjaan sesuai dengan posisi, kewenangan dan jabatan masing-masing. Selain itu, pimpinan perusahaan juga memberi karyawan kesempatan untuk mengikuti pelatihan dan penilaian karya. Kompensasi yang diberikan kepada karyawan juga sesuai dengan UMR kabupaten Pati, bahkan setiap bulan pimpinan perusahaan memberikan bonus-bonus tersendiri di luar gaji pokok karyawan. Kesehatan dan keselamatan kerja karyawan juga telah terjamin dengan adanya asuransi jiwa. Namun pada kenyataannya, 
kinerja karyawan dalam perusahaan ini masih tergolong rendah, mengingat banyak karyawan yang tidak bisa memproduksi sesuai jumlah target yang diinginkan oleh perusahaan. Tercatat dari tujuh bulan terakhir di tahun 2016, mulai bulan Januari yaitu karyawan mampu menghasilkan 4.000 unit barang. Kemudian pada bulan Februari mampu menghasilkan 4.500 unit barang, bulan Maret menghasilkan 5.000 unit barang, bulan April menghasilkan 5.500 unit barang, bulan Mei menghasilkan 5.700 unit barang, bulan Juni menghasilkan 4.000 unit barang, bulan Juli menghasilkan 4.500 dan bulan Agustus menghasilkan 5.800 unit barang. Sementara itu, perusahaan mengharapkan karyawan mampu menghasilkan 6.000 unit barang pada setiap bulannya, sedangkan pada kenyataannya hasil produksi pada tahun 2016 ini belum pernah mencapai target yang diharapkan perusahaan. Namun demikian, terjadinya kenaikan hasil produksi yang hampir mencapai target pada bulan April, Mei dan Agustus tidak lepas dari adanya dorongan ataupun strategi pemberdayaan karyawan yang dilakukan oleh pimpinan UD. Zidan Collection. Selain mengenai hasil produksi, absensi dan keterlambatan dalam bekerja masih sering terjadi.

Oleh sebab itu, dari beberapa latar belakang diatas peneliti tertarik untuk melakukan penelltian yang berjudul : "Analisis Strategi Pengelolaan Kualitas Kehidupan Kerja dalam Meningkatkan Kinerja Karyawan UD. Zidan Collection Tayu-Pati".

\section{B. Kajian Pustaka}

\section{Kualitas Kehidupan Kerja (Quality of Work Life)}

Kualitas kehidupan kerja (quality of work life) merupakan salah satu pendekatan sistem manajemen untuk mengkoordinasikan dan menghubungkan potensi sumber daya manusia, dimana kualitas kehidupan kerja dalam organisasi sebagai suatu upaya pimpinan untuk memenuhi kebutuhan anggota maupun organisasi secara simultan dan berkesinambungan. Menurut David A. Nadler dan Edward W. Lawler (dalam Cepi, 2015) mendeskripsikan kualitas kehidupan kerja (quality of work life) sebagai sebuah perhatian atau kepedulian terhadap dampak kerja/pekerjaan terhadap orang dan efektivitas organisasi yang digabungkan dengan upaya untuk mengikutsertakan pegawai dalam pemecahan 
masalah dan pembuatan keputusan. Dapat dipahami bahwa kualitas kehidupan kerja ini terkait dengan manajemen lembaga, khususnya bagaimana melibatkan pegawai dalam pemecahan masalah dan pembuatan keputusan.

Berdasarkan beberapa pengertian di atas, maka dapat disimpulkan bahwa kualitas kehidupan kerja dipandang sebagai sekumpulan persepsi karyawan mengenai rasa aman dalam bekerja, kepuasan kerja, serta kondisi untuk tumbuh dan berkembang sebagai manusia yang bertujuan untuk meningkatkan martabat karyawan. Oleh sebab itu, esensi kualitas kehidupan kerja bagi karyawan merupakan upaya untuk meningkatkan kesejahteraan, meningkatkan kepuasan kerja, meningkatkan kinerja, memenuhi harapan dan kebutuhan keluarga, serta memenuhi harapan karyawan seperti kehidupan yang lebih baik, kehidupan kerja yang lebih berarti dan bermanfaat bagi dirinya.

\section{a. Indikator Kualitas Kehidupan Kerja}

Ada tiga indikator kualitas kehidupan kerja yang dikemukakan oleh Cascio Wayne (dalam Arifin, 2012) yaitu:

1) Sistem imbalan yang inovatif. Imbalan yang diberikan kepada karyawan memungkinkan mereka untuk memuaskan berbagai kebutuhannya sesuai dengan standard hidup karyawan yang bersangkutan dan sesuai dengan standard pengupahan dan penggajian yang berlaku di pasaran kerja, mencakup gaji, tunjangan, bonus-bonus, dan berbagai fasilitas lain sebagai imbalan jerih payah karyawan dalam bekerja.

2) Lingkungan kerja. Tersedianya lingkungan kerja yang kondusif, termasuk di dalamnya penetapan jam kerja, peraturan yang berlaku kepemimpinan dan lingkungan fisik. Lingkungan ini sangat penting terutama bagi keselamatan dan kenyamanan karyawan dalam menjalankan tugasnya.

3) Restrukturisasi kerja yaitu memberikan kesempatan bagi karyawan untuk mendapatkan pekerjaan yang tertantang (job enrichment) dan kesempatan yang lebih luas untuk pengembangan diri. Sehingga dapat mendorong karyawan untuk lebih mengembangkan potensi dirinya. 
Sedangkan Hadari (2011) mengemukakan bahwa terdapat sembilan aspek pada sumber daya manusia di lingkungan perusahaan yang perlu diciptakan, dibina, dan dikembangakan demi tercapainya kualitas kehidupan kerja yaitu:

1) Komunikasi. Di setiap lingkungan organisasi atau perusahaan, karyawan memerlukan komunikasi yang terbuka dalam batas-batas wewenang dan tanggung jawab masing-masing. Dengan komunikasi yang lancar maka karyawan akan mendapat informasi-informasi penting secara tepat dan juga dapat menimbulkan rasa puas serta merupakan motivasi kerja yang positif.

2) Penyelesaian konflik. Di lingkungan suatu perusahaan, setiap karyawan memiliki kesempatan untuk memberikan sumbangan dalam memecahkan konflik di perusahaan maupun konflik antar karyawan secara terbuka, jujur dan adil. Kondisi tersebut sangat berpengaruh pada loyalitas dan dedikasi serta motivasi karyawan.

3) Pengembangan karier. Di lingkungan suatu perusahaan, setiap karyawan memerlukan kejelasan tentang pengembangan karier mereka dalam menghadapi masa depan. Untuk itu dapat ditempuh melalui penawaran kenaikan jabatan, memberi kesempatan mengikuti pelatihan dan penilaian karya.

4) Partisipasi kerja. Di lingkungan suatu perusahaan, setiap karyawan perlu diikutsertakan dalam proses pengambilan keputusan dan pelaksanaan pekerjaan sesuai dengan posisi, kewenangan dan jabatan masing-masing.

5) Kebanggaan. Di lingkungan suatu perusahaan, setiap karyawan perlu dibina dan dikembangkan perasaan bangganya pada tempatnya bekerja, termasuk juga pada pekerjaan atau jabatannya. Untuk keperluan itu perusahaan berkepentingan menciptakan dan mengembangkan identitas yang dapat menimbulkan rasa bangga karyawan pada perusahaan. Dalam bentuk yang sederhana dapat dilakukan melalui logo, lambang, jaket perusahaan dan lain-lain.

6) Kompensasi. Di lingkungan suatu perusahaan, setiap karyawan harus memperoleh kompensasi yang adil/wajar dan mencukupi. Untuk itu diperlukan kemampuan menyusun 
dan menyelenggarakan sistem dan struktur pemberian kompensasi langsung dan tidak langsung (pemberian upah dasar dan berbagai keuntungan/manfaat) yang kompetitif dan dapat mensejahterakan kehidupan karyawan sesuai posisi/jabatannya di perusahaan dan status ekonominya di masyarakat.

7) Keselamatan Lingkungan. Di lingkungan suatu perusahaan, setiap karyawan memerlukan keamanan lingkungan kerja. Untuk itu perusahaan berkewajiban menciptakan dan mengembangkan serta memberi jaminan lingkungan kerja yang aman.

8) Keselamatan kerja. Di lingkungan suatu perusahaan, setiap karyawan memerlukan rasa aman atau jaminan kelangsungan pekerjaannya. Untuk itu perusahaan perlu berusaha menghindari pemberhentian sementara para karyawan, menjadikannya sebagai pekerja/karyawan tetap dengan memiliki tugas-tugas reguler dan memiliki program yang teratur dalam memberikan kesempatan karyawan untuk mengundurkan diri, terutama melalui pengaturan pensiun.

9) Kesehatan kerja. Di lingkungan suatu perusahaan, setiap karyawan memerlukan perhatian terhadap pemeliharaan kesehataannya agar dapat bekerja secara efektif, efisien dan produktif. Untuk itu perusahaan dapat mendirikan dan menyelenggarakan program pemeliharaan kesehatan, program rekreasi dan program konseling/penyuluhan bagi karyawan.

\section{b. Kinerja Karyawan}

Suatu perusahaan tentu membutuhkan karyawan sebagai tenaga kerjanya guna meningkatkan produk yang berkualitas. Mengingat karyawan merupakan aset penting bagi perusahaan, banyak hal yang perlu diperhatikan terkait dengan peningkatan kinerjanya.

Menurut Anwar Prabu Mangkunegara (2013) kinerja adalah hasil kerja secara kualitas dan kuantitas yang dicapai oleh seorang karyawan dalam melaksanakan tugasnya sesuai dengan tanggung jawab yang diberikan kepadanya. 
McCloy et.al. mengemukakan bahwa kinerja juga bisa berarti perilaku-perilaku atau tindakan-tindakan yang relevan terhadap tercapainya tujuan organisasi (goal-relevant action). Tujuan-tujuan tersebut bergantung pada wewenang penilai yang menentukan tujuan apa yang harus dicapai oleh karyawan. Agar seseorang melakukan suatu tugas sesuai dengan kinerja yang diinginkan, prasyarat yang harus dipenuhi adalah memiliki pengetahuan dan keterampilan-keterampilan yang dibutuhkan serta membuat pilihan dengan sungguh-sungguh untuk bekerja pada tugas dan pekerjaannya selama beberapa tenggang waktu tertentu dengan tingkat usaha tertentu. Sejalan dengan hal tersebut, Schultz (dalam Khaerul: 2012) menyatakan bahwa karyawan akan mampu memotivasi diri mereka sepenuhnya jika ada tujuan pasti yang ingin diraih. Tujuan tersebut adalah hasil yang akan dicapai oleh karyawan dan memberikan arah pada perilaku dan pikiran mereka sehingga membimbingnya untuk meraih tujuan yang hendak dicapai.

Disamping itu, Cherington menyatakan bahwa kinerja menunjukkan pencapaian target kerja yang berkaitan dengan kualitas, kuantitas dan waktu. Pencapaian kinerja tersebut dipengaruhi oleh kecakapan dan waktu. Kinerja yang optimal akan terwujud apabila organisasi dapat memilih karyawan yang memiliki motivasi dan kecakapan yang sesuai dengan pekerjaannya serta memiliki kondisi yang memungkinkan mereka agar bekerja secara maksimal.

Dari beberapa pengertian kinerja yang disampaikan oleh para ahli tersebut, dapat disimpulkan bahwa pengertian kinerja adalah hasil kerja yang dicapai oleh individu sesuai dengan peran atau tugasnya dalam periode tertentu, yang dihubungkan dengan ukuran nilai atau standar tertentu dari organisasi tempat individu tersebut bekerja.

Faktor yang mempengaruhi pencapaian kinerja adalah faktor kemampuan (ability) dan faktor motivasi (motivation).

1) Faktor kemampuan. Secara psikologis, kemampuan (ability) pegawai terdiri atas kemampuan potensi (IQ) dan kemampuan realita (pendidikan). Oleh karena itu, 
pegawai perlu ditempatkan pada pekerjaan yang sesuai dengan keahliannya.

2) Faktor motivasi. Faktor ini terbentuk dari sikap (attitude) seorang pegawai dalam menghadapi situasi kerja. Motivasi merupakan kondisi yang menggerakkan pegawai kearah pencapaian tujuan orgnisasi (tujuan kerja) (Mangkunegara: 2013). Selain itu, Gibson (dalam Khaerul: 2012) menyatakan bahwa terdapat tiga faktor lain yang berpengaruh terhadap kinerja, yaitu:

- Faktor individu: kemampuan, keterampilan, latar belakang keluarga, pengalaman kerja, tingkat sosial, dan demografi seseorang.

- Faktor psikologi: persepsi, peran, sikap, kepribadian, motivasi dan kepuasan kerja.

- Faktor organisasi: struktur organisasi, desain pekerjaan, kepemimpinan, sistem penghargaan (reward system).

Indikator kinerja merupakan aspek-aspek yang menjadi ukuran dalam menilai kinerja. Ukuran kinerja sangat diperlukan karena akan bermanfaat baik bagi banyak pihak. John Miner mengemukakan bahwa terdapat empat indikator yang dapat dijadikan sebagai tolok ukur dalam menilai kinerja, yaitu:

1) Kualitas, yaitu; tingkat kesalahan, kerusakan dan kecermatan.

2) Kuantitas, yaitu; jumlah pekerjaan yang dihasilkan.

3) Pengunaan waktu dalam kerja, yaitu; tingkat ketidakhadiran, keterlambatan, waktu kerja efektif/ jam kerja hilang.

4) Kerja sama dengan orang lain dalam bekerja. (Sudarmanto: 2014)

Dari empat dimensi kinerja diatas, dua hal terkait dengang aspek keluaran atau hasil pekerjaan, yaitu: kualitas hasil, kuantitas keluaran, dan dua hal terkait dengan aspek perilaku individu, yaitu: penggunan waktu dalam kerja (tingkat kepatuhan terhadap jam kerja, disiplin) dan kerja sama. Dari empat dimensi kinerja tersebut cenderung mengukur kinerja pada level individu.

Sedangkan Jerry Harbour merekomendasikan pengukuran kinerja dengan enam aspek, yaitu: 
1) Produktivitas: kemampuan dalam menghasilkan produk barang dan jasa.

2) Kualitas: pemroduksian barang dan jasa yang dihasilkan memenuhi standar kualitas.

3) Ketepatan waktu (timeliness): waktu yang diperlukan dalam menghasilkan produk barang dan jasa tersebut.

4) Putaran waktu: waktu yang dibutuhkan dalam setiap proses perubahan barang dan jasa tersebut kemudian sampai kepada pengguna/konsumen.

5) Penggunaan sumber daya: sumber daya yang diperlukan dalam menghasilkan produk dan jasa tersebut.

6) Biaya: biaya yang diperlukan.

\section{Penelitian Terdahulu}

1. Penelitian yang dilakukan oleh Ocky Adhi Prakoso, dengan judul "Quality Of Work Life: Studi Indigenous Pada Guru Bersuku Jawa di Jawa Tengah Tahun 2013". Dalam penelitian tersebut dijelaskan bahwa quality of work life menurut guru bersuku Jawa di Jawa Tengah yaitu suatu kondisi atau kualitas kehidupan guru pada tempat mereka bekerja. Berdasarkan hasil penelitian yang dilakukan pada guru bersuku Jawa di Jawa Tengah ditemukan 12 (dua belas) faktor yang mempengaruhi quality of work life yaitu lingkungan kerja yang kondusif, motivasi kerja, kesejahteraan, dukungan keluarga, kesehatan, beban kerja, kepuasan kerja, kompetensi diri, kesesuaian pekerjaan dengan keinginan, loyalitas kerja, kedisiplinan serta reward dan kesempatan berkembang.

2. Penelitian Halil Ibrahim, Sascha, Gultekin, Jikmet dan Erdal, dengan judul "Evaluation of Working Life Quality For A Textile Company in Turkey: A Case Study (Evaluasi Kualitas Kehidupan Kerja untuk Sebuah Perusahaan Tekstil di Turki : Sebuah Studi Kasus) Tahun 2011". Dalam penelitian tersebut bahwa kualitas kehidupan kerja karyawan perusahaan tekstil bangsa Turki belum begitu baik, sehingga kinerja karyawan rendah. Hal tersebut dikarenakan motivasi yang rendah dan beban kerja yang tinggi. 
3. Penelitian Noor Arifin dengan judul "Analisis Kualitas Kehidupan Kerja, Kinerja, dan Kepuasan Kerja pada CV. Duta Senenan Jepara Tahun 2012". Dalam penelitian ini menunjukkan bahwa semakin baik kualitas kehidupan kerja karyawan, sangat berpengaruh terhadap kinerja karyawannya. Disamping itu, semakin tinggi perasaan puas karyawan akan semakin memacu terhadap semangat kinerjanya. Namun dalam penelitian ini menunjukkan bahwa kualitas kehidupan kerja tidak berpengaruh terhadap kepuasan karyawan.

Dalam mempertahankan eksistensi organisasi berhubungan erat dengan manajemen sumber daya manusia pada setiap organisasi bisnis, baik besar maupun kecil. Dengan kata lain, dunia bisnis memerlukan kemampuan memahami, menerima dan menyesuaikan diri dengan berbagai pergeseran dan perubahan lingkungan, melaui manajemen sumber daya manusia yang mampu menghargai martabat dan harkat manusia. Dalam pendekatan sumber daya manusia berarti setiap organisasi/perusahaan harus mampu menciptakan rasa aman dan kepuasan dalam bekerja (Quality of Work Life disingkat QWL), agar sumber daya manusia di lingkungannya menjadi kompetitif (Hadari: 2011).

Dengan kualitas kehidupan kerja (QWL) yang dapat meningkatkan kinerja dan menjadikan sumber daya manusia kompetitif, maka secara keseluruhan organisasi akan menjadi kompetitif pula dalam mewujudkan eksistensinya.

Misalnya UD. Zidan Collection Tayu Pati, menjadi sorotan utama mengenai kualitas kehidupan kerja karyawan, karena dari awal berdiri hingga sekarang banyak karyawan lama yang masih setia bekerja di perusahaan tersebut. Tujuan dari penerapan atau pengelolaan kualitas kehidupan kerja tersebut yaitu untuk menciptakan sumber daya manusia yang berkualitas atau meningkatkan kinerja karyawan di dalam organisasinya, sehingga akhirnya akan mengantarkan pada eksistensi organisasi atau perkembangan organisasi ke arah yang lebih baik. 
Gambar 1. Gambar Kerangka Berfikir

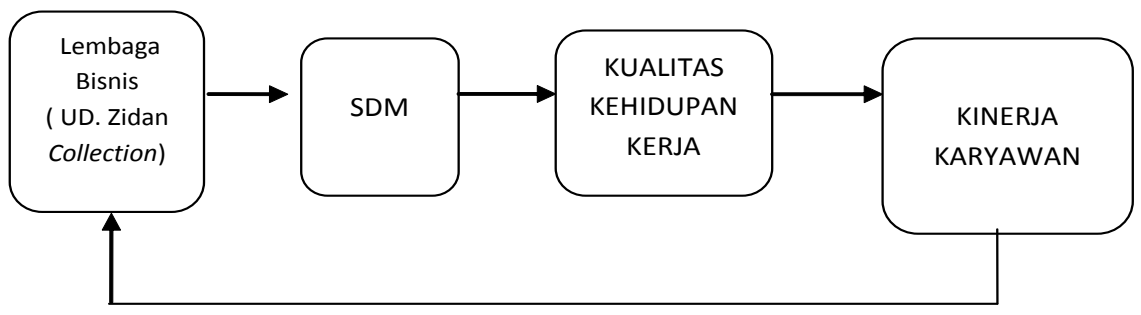

\section{Metode Penelitian}

Penelitian ini termasuk jenis penelitian lapangan (field research), yaitu sebuah studi penelitian yang mengambil data autentik secara obyektif. Dilihat dari jenisnya penelitian ini termasuk penelitian kualitatif dengan menggunakan metode deskriptif. Sedangkan Pendekatan yang dilakukan dalam penelitian ini menggunakan teknik pendekatan kualitatif.

Sumber data yang dipakai oleh peneliti adalah sumber primer dan sekunder. Sumber data primer adalah sumber data yang langsung memberikan data kepada pengumpul data, misalnya melalui wawancara langsung dengan pimpinan dan karyawan konveksi UD. Zidan Collection. Sedangkan Sumber data sekunder merupakan sumber yang tidak langsung memberikan data kepada pengumpul data misalnya lewat orang lain atau lewat dokumen-dokumen yang dimiliki oleh UD. Zidan Collection. Tehnik pengumpulan data melalui metode observasi/pengamatan, wawancara dan dokumentasi.

Tehnik analisis data melalui tiga jalur analisis data kualitatif, yaitu reduksi data, penyajian data dan penarikan kesimpulan ( Ariesto: 2010) :

1. Reduksi data merupakan bentuk analisis yang menajamkan, menggolongkan, mengarahkan, membuang yang tidak perlu, dan mengorganisasi data sedemikian rupa sehingga kesimpulan akhir dapat diambil.

2. Penyajian data adalah kegiatan ketika sekumpulan informasi disusun, sehingga memberi kemungkinan akan adanya penarikan kesimpulan. Bentuk penyajian data kualitatif 
berupa teks naratif (berbentuk catatan lapangan), matriks, grafik, jaringan, dan bagan.

3. Penarikan kesimpulan merupakan hasil analisis yang dapat digunakan untuk mengambil tindakan.

\section{E. Pembahasan}

\section{Analisis Strategi Pengelolaan Kualitas Kehidupan Kerja dalam Meningkatkan Kinerja Karyawan}

Berdasarkan hasil wawancara dengan pimpinan, dapat dikemukakan bahwa kinerja karyawan di UD. Zidan Collection belum seluruhnya karyawan yang bekerja di perusahaan ini memiliki kinerja yang bagus, sehingga pimpinan perlu untuk menerapkan strategi dalam meningkatkan kinerja karyawan. Pengelolaan kualitas kehidupan kerja merupakan strategi yang digunakan UD. Zidan Collection untuk meningkatkan kinerja karyawan. Strategi tersebut mengembangkan sembilan aspek kualitas kehidupan kerja yang sejalan dengan pendapat Hadari Nawawi, yaitu: komunikasi, keterlibatan karyawan dalam penyelesaian konflik, partisipasi kerja, pengembangan karir, kompensasi yang layak, keselamatan kerja, keselamatan lingkungan, kesehatan kerja serta pengembangan perasaan bangga karyawan.

Strategi pengelolaan yang digunakan oleh UD. Zidan Collection tersebut merupakan pendekatan Human Resources Approach (pendekatan sumber daya manusia), dimana pengelolaan sumber daya manusia dalam perusahaan ini berpegang pada penghargaan manusia yang menjunjung tinggi martabat dan kepentingan hidup manusia menjadi dasar setiap kebijakan manajemen, agar kehidupan karyawan lebih layak dan sejahtera.

Karyawan merupakan asset utama dari suatu organisasi yang memiliki peran yang strategis, yaitu sebagai pemikir, perencana, dan pelaksana aktivitas organisasi. Untuk meningkatkan citra, kerja dan kinerja menuju kearah professionalisme, diperlukan adanya suasana yang baik dalam lingkungan kerja karyawan itu sendiri. Suasana yang baik tersebut dapat terbangun apabila terjalin komunikasi yang baik juga antara pimpinan dengan seluruh karyawan. Terjalinnya komunikasi yang baik antara pimpinan 
dan karyawan tersebut tentu akan menyebabkan karyawan mau untuk menginterpretasikan kemauan dan harapan pimpinan dalam kinerjanya.

Hal ini sesuai dengan pendapat Edwin B. Flippo dalam Mangkunegara, 2014 bahwa komunikasi adalah aktivitas yang menyebabkan orang lain menginterpretasikan suatu ide, terutama yang dimaksudkan oleh pembicara atau penulis. Dengan demikian, bentuk perilaku yang terjadi ketika seseorang terlibat dalam komunikasi adalah menafasirkan pertujukan-pesan dari pembicara. Jadi, dalam sebuah organisasi seperti perusahaan, komunikasi merupakan salah satu bentuk tindakan/perilaku manajerial yang sangat dibutuhkan. Tanpa komunikasi organisasi tidak akan berjalan dengan baik.

Begitu juga dengan keterlibatan karyawan dalam menyelesaikan sebuah konflik dalam sebuah organisasi/ perusahaan merupakan hal yang penting. Kebanyakan orang punya kecenderungan akan menghindari konflik meskipun pada kenyataannya semua manusia pasti akan mengalami konflik baik dengan dirinya maupun orang lain. Demikian pula halnya dalam berorganisasi, sungguh naif bila konflik tidak dipandang sebagai aspek penting dalam menentukan maju mundurnya sebuah organisasi termasuk sebuah perusahaan. Berdasarkan hal itu, pengelola lembaga/perusahaan membutuhkan perspektif dan tanggung jawab yang lebih luas dalam penanganan konflik tersebut.

Hal ini juga sesuai dengan pandangan kontemporer yang menganggap bahwa konflik lazim terjadi dalam berbagai komunikasi. Tidak ada dua orang yang selalu indentik dalam merasa, berfikir, dan bertindak. Konflik sebagai suatu fakta kehidupan yang tidak perlu diartikan bahwa organisasi dalam keadaan bahaya. Di sini yang terpenting bukan banyaknya keberadaan konflik, tetapi bagaimana konflik ditangani dengan menggunakan pendekatan pengelolaan dan penyelesaian konflik secara tepat. (Triatna: 2015). Bagi UD. Zidan Collection pemberian kesempatan kepada seluruh karyawan untuk menyelesaikan permasalahan yang dihadapi, baik dengan mandor maupun dengan sesama karyawan yang lain secara musyawarah untuk mencari jalan keluar dari permasalahan 
yang dihadapinya merupakan salah satu strategi yang baik dalam mengelola kinerja karyawan.

Partisipasi kerja juga merupakan aspek penting lainnya yang menentukan kinerja karyawan. Bentuk partisipasi kerja yang dilaksanakan di UD. Zidan Collection adalah dengan mengikutsertakan seluruh karyawan dalam rapat untuk membahas masalah produksi. Keikutsertaan karyawan dalam ikutserta memberikan masukan dalam pengambilan sebuah keputusan tentu akan berrdampak baik bagi peningkatan kinerja.

Dalam kaitannya dengan hal itu, menurut Abdul Azis Wahab (2011) bahwa keputusan yang diambil oleh pimpinan termasuk dalam bentuk sentralisasi demokratis, yaitu prosedur pengambilan putusan dengan cara pemimpin mengemukakan masalah dan bawahan diminta untuk memberikan saran-saran. Jadi, keikutsertaan karyawan dalam mengambil keputusan akan dapat menumbuhkan rasa dihargainya karyawan sehingga ia merasa memiliki dan bertanggung jawab atas keputusan yang diambil tersebut. Hal ini tentu akan menumbuhkan motivasi dan kinerja karyawan.

Pengembangan karir yang dilaksanakan di UD. Zidan Collection dilaksanakan dengan memberikan pelatihan kepada karyawan baru yang masih minim pengalaman, sehingga karyawan kemampuan dan keterampilannya menjadi bertambah. Hal ini sesuai dengan pendapat Hasibuan (2012) yang menyatakan bahwa pengembangan adalah suatu usaha untuk meningkatkan kemampuan teknis, teoretis, konseptual dan moral karyawan sesuai dengan kebutuhan pekerjaan/jabatan melalui pendidikan dan latihan. Pengembangan karyawan dirasa semakin bermanfaat dikarenakan adanya faktor peningkatan jabatan maupun pekerjaan, sebagai akibat dari adanya kemajuan di bidang teknologi dan juga sebagai akibat dari adanya globalisasi.

Bagi sebuah perusahaan, keberhasilan pengembangan karir dapat dilihat dari prestasi kerja yang memuaskan. Hal ini sebagaimana yang dijelaskan oleh Siagian (1996) bahwa pangkal tolak pengembangan karir seseorang adalah prestasi kerjanya melakukan tugas yang dipercayakan kepadanya sekarang. Tanpa 
prestasi kerja yang memuaskan, sukar bagi seseorang pekerja untuk diusulkan oleh atasannya agar dipertimbangkan untuk dipromosikan ke pekerjaan atau jabatan yang lebih tinggi di masa depan. Jadi belum adanya promosi jabatan di UD. Zidan Collection merupakan hal yang sudah sesuai karena masih banyak karyawan yang belum menunjukkan prestasi kerja yang baik.

Sementara kenyamanan dalam lingkungan bekerja dapat menciptakan tingkat produktivitas karyawan yang sesuai dengan tujuan organisasi. Peningkatan kualitas kehidupan kerja seseorang dapat memiliki dampak positif pada peningkatan kepuasan kerja terhadap organisasi, seperti tingkat absensi dan kinerja karyawan. Berdasarkan hal tersebut, maka bagi karyawan diperlukan perhatian lebih serius terhadap tugas yang dikerjakan sehingga tujuan organisasi tercapai. Dengan adanya kualitas kehidupan kerja yang baik, karyawan akan bekerja lebih giat di dalam melaksanakan pekerjaannya. Sebaliknya dengan kualitas kehidupan kerja yang rendah, maka karyawan akan menghadapi kesulitan dalam menyelesaikan pekerjaannya yang nantinya akan berpengaruh pada kinerjanya.

Hal ini sesuai dengan penelitian terdahulu yang dikemukakan oleh Noor Arifin (2012) yang menyimpulkan bahwa semakin baik kualitas kehidupan kerja karyawan, sangat berpengaruh terhadap kinerjanya. Lingkungan kerja yang baik dapat mendukung pelaksanaan kerja sehingga karyawan memiliki semangat bekerja dan meningkatkan kinerja karyawan. Untuk menciptakan kinerja yang tinggi, dibutuhkan adanya peningkatan kerja yang optimal dan mampu mendayagunakan potensi sumber daya manusia yang dimiliki oleh karyawan guna menciptakan tujuan organisasi, sehingga akan memberikan kontribusi positif bagi peningkatkan kinerja karyawan.

\section{Analisis Faktor Pendukung dan Penghambat UD. Zidan Collection dalam Meningkatkan Kinerja Karyawan}

Berdasarkan dari sajian data faktor pendukung UD Zidan Collection dalam meningkatkan kinerja karyawan dapat diketahuai ada 3 (tiga) faktor, yaitu: 1) adanya pemberian bonus kepada 
karyawan, 2) adanya asuransi bagi karyawan, dan 3) tersedianya fasilitas yang mendukung kenyamanan karyawan dalam bekerja.

Adanya pemberian bonus di UD Zidan Collection merupakan salah satu sistem insentif sebagai bagian dari sistem imbalan yang berlaku bagi para karyawan organisasi. Pemberian bonus ditujukan untuk lebih mendorong produktivitas kerja yang lebih tinggi. Insentif dalam bentuk bonus diberikan pada karyawan yang mampu bekerja sedemikian rupa sehingga tingkat produksi yang baku terlampaui. Bagi UD. Zidan Collection pemberian bonus ini didasarkan pada berdasarkan jumlah unit produksi yang mampu dihasilkan oleh karyawan dalam satu kurun waktu tertentu. Jika jumlah unit produksi yang dihasilkan melebihi jumlah yang telah ditetapkan, maka karyawan menerima bonus atas kelebihan jumlah yang telah dihasilkannya itu.

Hal ini sesuai dengan pendapat Siagian: 1996, bahwa guna mendorong produktivitas kerja yang lebih tinggi, banyak organisasi yang menganut sistem insentif sebagai bagian dari sistem imbalan yang berlaku bagi para karyawan organisasi. Berbagai sistem insentif yang dikenal dewasa ini dapat digolongkan pada dua kelompok utama, yaitu sistem insentif pada tingkat individual dan pada tingkat kelompok. Bonus merupakan salah satu sistem individual.

Asuransi sebagai bagian dari keselamatan lingkungan dan kesehatan kerja yang diberikan oleh UD. Zidan Collection dapat menjadi pendukung meningkatnya kinerja karyawan. Keselamatan lingkungan kerja menunjukkan kondisi yang aman atau selamat dari penderitaan, kerusakan atau kerugian di tempat kerja. Risiko keselamatan lingkungan kerja merupakan aspek-aspek dari lingkungan kerja yang dapat menyebabkan kebakaran, kerugian alat tubuh, penglihatan, maupun pendengaran. Sedangkan kesehatan kerja menunjukkan pada kondisi yang bebas dari gangguan fisik, mental, emosi atau rasa sakit yang disebabkan oleh lingkungan kerja. Dengan adanya asuransi ini, karyawan menjadi nyaman untuk bekerja karena apabila terjadi risiko gangguan fisik maka sudah ada pihak yang menanggung biayanya.

Hal ini sesuai dengan pendapat Mangkunegara (2014) bahwa tujuan keselamatan dan kesehatan kerja adalah agar setiap pegawai 
mendapat jaminan keselamatan dan kesehatan kerja baik secara fisik, sosial, dan psikologis sehingga pegawai merasa aman dan terlindungi dalam bekerja. Keselamatan lingkungan kerja tersebut merupakan situasi dimana pekerja merasa aman dan nyaman dengan lingkungan kerja dan berpengaruh kepada produktivitas dan kualitas bekerja.

Sedangkan tersedianya fasilitas juga turut serta mendukung kinerja karyawan. Tercukupinya fasilitas perusahan dapat mendukung kenyamanan kerja karyawan, sehingga motivasi dan kinerja karyawan menjadi meningkat. Rasa nyaman muncul dengan alat pelindung diri untuk keselamatan kerja, alat-alat yang digunakan, dan tata letak ruang kerja saat bekerja.

Fasilitas kerja tersebut sebagai alat atau sarana dan prasarana untuk membantu karyawan agar lebih mudah menyelesaikan pekerjaannya dan karyawan akan bekerja lebih produktif. Lingkungan kerja yang kondusif akan membuat karyawan betah dan merasa nyaman untuk melaksanakan pekerjaan yang di bebankan kepadanya. Kondisi lingkungan kerja secara tidak langsung akan mempengaruhi emosi karyawan. Ketika karyawan tidak merasa nyaman dengan lingkungan kerjanya maka kemungkinan untuk meraih kinerja optimal dari karyawan itu sangatlah kecil.

Adapun yang menjadi faktor penghambat yang terjadi pada UD. Zidan Collection adalah tingkat pendidikan karyawan masih rendah dan sebagian besar karyawan Ibu rumah tangga. Tingkat pendidikan karyawan yang masih rendah menyebabkan kemampuan dan keahlian yang dimiliki oleh karyawan kurang luas, sehingga dalam melaksanakan kerjanya masih kurang baik. Tingkat pendidikan yang rendah juga dapat menjadikan kurangnya pengetahuan karyawan dalam memahami tugas-tugas yang diberikan oleh atasan masih sering terjadi seperti pemahaman akan kode barang yang tertera pada barang produksi. Kesalahan seperti ini sering kali terjadi terutama bagi karyawan baru yang ditugaskan oleh atasannya. Hal ini memungkinkan timbulnya salah paham antar karyawan di lokasi kerja dan megakibatkan konsumen harus menunggu lama untuk mendapatkan barang yang akan dibeli. Oleh karena itu, sering kali konsumen kecewa akan pelayanan yang 
diberikan sehingga mereka lebih memilih untuk mencari barang serupa di tempat lain daripada harus menunggu lama.

Begitu juga dengan pekerjaan karyawan yang sebagian besar adalah ibu rumah tangga yang menyebabkan banyaknya kesibukan di rumah. Banyaknya kesibukan di rumah biasanya dapat menjadikan mereka sering telat masuk dan juga kurang bersemangat dalam bekerja karena sudah lelah terlebih dahulu dalam mengerjakan tugas di rumah. Hal ini tentu menjadi perhatian dari pimpinan agar tingkat pendidikan dan kesibukan karyawan sebagai ibu rumah tangga tidak mengganggu kinerja karyawan di perusahaan.

Perusahaan UD. Zidan Collection telah memberi berbagai motivasi baik berupa bonus, asuransi BPJS, THR, rekreasi, tempat kerja yang aman dan nyaman untuk karyawan, namun pada kenyataannya kinerja karyawan masih rendah.

Hal tersebut tentunya dikarenakan kemampuan (ability) pegawai yang terdiri atas kemampuan potensi (IQ) dan kemampuan realita (pendidikan) masih tergolong rendah.

\section{F. Simpulan dan Saran}

\section{Simpulan}

Strategi pengelolaan kualitas kehidupan kerja UD. Zidan Collection dalam meningkatkan kinerja karyawan dilaksanakan melalui pengembangan sembilan aspek kualitas kehidupan kerja, yaitu : komunikasi interaktif yang terbuka, keterlibatan karyawan dalam penyelesaian konflik melalui musyawarah, pengembangan karir dengan memberikan pelatihan, partisipasi kerja dengan mengikutsertakan seluruh karyawan dalam rapat, membangun rasa bangga karyawan dengan mengadakan rekreasi setahun sekali dan memberikan THR, kompensasi yang layak dengan pemberian bonus bagi yang berprestasi, keselamatan lingkungan dengan memberikan lingkungan kerja yang bersih, aman dan nyaman dengan adanya musik saat kerja, keselamatan kerja dengan menjadikan semua karyawan sebagai karyawan tetap, serta kesehatan kerja yang diberikan berupa mengikutsertakan seluruh karyawan sebagai anggota BPJS ketenagakerjaan. 
Faktor yang menjadi pendukung dalam meningkatkan kinerja karyawan UD. Zidan Collection, yaitu adanya pemberian bonus kepada karyawan, adanya asuransi bagi karyawan, dan tersedianya fasilitas yang mendukung kenyamanan karyawan dalam bekerja. Sedangkan yang menjadi faktor penghambatnya adalah tingkat pendidikan karyawan masih rendah dan sebagian besar karyawan merupakan Ibu rumah tangga.

\section{Saran}

\section{a. Untuk UD. Zidan Collection}

Sebaiknya pimpinan dalam rekrutmen karyawan baru perlu untuk diperhatikan tingkat pendidikan pekerja, minimal tenaga kerja baru lulusan SMA/Madrasah Aliyah. Perlu diadakan sistem evaluasi kinerja secara keseluruhan atau semua unit bagian guna lebih memaksimalkan perbaikan secara teratur dan perubahan untuk lebih menunjang kemajuan perusahaan. Sebaiknya pemimpin membuat logo perusahaan dan seragam untuk semua karyawan, guna meningkatkan rasa bangga karyawan.

\section{b. Untuk Peneliti Selanjutnya}

Untuk peneliti selanjutnya, disarankan untuk meneliti pada perspektif yang berbeda, contohnya tentang kepuasan konsumen atau penilaian kinerja dengan pendekatan kuantitatif sehingga menambah khazanah keilmuwan. 


\section{DAFTAR PUSTAKA}

Abdul Azis Wahan, Anatomi Organisasi dan Kepemimpinan Pendidikan, Alvabeta, Bandung, 2011.

Anwar Prabu Mangkunegara, Manajemen Sumber Daya Manusia Perusahaan, Remaja Rosdakarya, Bandung, 2013.

Ariesto Hadi Sutopo dan Adrianus Arief, Terampil Mengolah Data Kualitatif dengan NVIVO, Prenada Media Group, Jakarta, 2010.

Cepi Triatna, Perilaku Organisasi, Remaja Rosdakarya, Bandung, 2015.

Danang Sunyoto, Manajemen Sumber Daya Manusia, CAPS (Center for Academic Publishing Service), Yogyakarta, 2013.

Hadari Nawawi, Manajemen Sumber Daya Manusia untuk Bisnis yang Kompetitif, Gajah Mada University Press, Yogyakarta, 2011.

Halil Ibrahim dkk, Evaluation of Working Life Quality for A Textile Company in Turkey : A Case Study, Gazi University Journal of Science, 2011.

Hasibuan, Manajemen Sumber Daya Manusia, Bumi Aksara, Jakarta,2012.

Khaerul Umam, Perilaku Organisasi, Pustaka Setia, Bandung, Cet. 2, 2012.

Noor Arifin, Analisis Kualitas Kehidupan Kerja, Kinerja, dan Kepuasan Kerja pada CV.Duta Senenan Jepara, Jurnal Economia, Vol. 8, No.1, 2012.

Ocky Adhi Prakoso, Quality of Work Life : Studi Indigenous Pada Guru Bersuku Jawa di Jawa Tengah, Journal of Social and Industrial Psychology, 2013.

Sudarmanto, Kinerja dan Pengembangan Kompetensi SDM, Pustaka Pelajar, Yogyakarta, 2014.

Sondang P. Siagian, Manajemen Sumber Daya Manusia, Bumi Aksara, Jakarta, 1996.

Wahibur Rokhman, Manajemen Sumber Daya Manusia, Nora Media Enterprise, Kudus, 2011. 